\title{
THE TRADE OF PINHÃO (Araucaria angustifolia SEED) IN MINAS GERAIS: A STIMULUS FOR CONSERVATION?
}

\author{
Ricardo Tayarol Marques ${ }^{1 *}$, Vanessa Cabral Costa de Barros ${ }^{2}$, Luís Antônio Coimbra Borges ${ }^{3}$, Ana Carolina \\ Maioli Campos Barbosa ${ }^{4}$
}

\author{
1*Instituto Federal de Educação, Ciência e Tecnologia do Sudeste de Minas Gerais, Campus Barbacena, Barbacena, Minas \\ Gerais, Brasil, ricardo.tayarol@ifsudestemg.edu.br \\ ${ }^{2}$ Universidade Federal de Lavras, Departamento de Ciências Florestais, Lavras, Minas Gerais, Brasil, \\ vanessacabralcb@gmail.com \\ ${ }^{3}$ Universidade Federal de Lavras, Departamento de Ciências Florestais, Lavras, Minas Gerais, Brasil, luis.borges@ufla.br \\ ${ }^{4}$ Universidade Federal de Lavras, Departamento de Ciências Florestais, Lavras, Minas Gerais, Brasil, anabarbosa@ufla.br
}

Received for publication: 27/08/2019 - Accepted for publication: 06/07/2020

\section{Resumo}

O comércio do pinhão (semente de Araucaria angustifolia) em Minas Gerais: um estímulo para conservação? O conhecimento sobre a produção e cadeias de comercialização do pinhão é centrada na região da Floresta Ombrófila Mista, no sul do Brasil. Diante dessa realidade, foi proposto avaliar a cadeia produtiva e de comércio do pinhão numa região de tensão ecológica, Floresta Estacional Semidecidual, e verificar a efetividade do comércio do pinhão como ferramenta para a conservação da araucária. $\mathrm{O}$ estudo foi baseado no levantamento estatístico sobre extração e comércio do pinhão, disponibilizado por instituições governamentais. Para identificar os estabelecimentos que atuam no comércio do pinhão em Minas Gerais, foram realizadas entrevistas estruturadas e revisão de literatura da legislação associada ao comércio de produtos florestais, estabelecendo a relação entre o comércio e conservação da araucária. Os resultados mostraram que Minas Gerais é o terceiro maior produtor nacional de pinhão, respondendo por 13,9\% da produção, e, dentre eles, apresenta a menor remuneração pelo produto extraído. Há o predomínio do comércio via cadeia curta, produtor ou varejista negociando com o consumidor, permitindo maiores lucros para os atores envolvidos, que se beneficiam da ausência de regulamentações especificas e fiscalizações na extração e comércio do pinhão, tornando a atividade predatória o que não contribuí para a preservação da araucária. Entretanto a adoção de instrumentos adequados poderá viabilizar a conservação da espécie, aliando assim o seu potencial de uso em projetos de restauração florestal com a renda advinda da comercialização do pinhão para que tenhamos uma ferramenta efetiva para a conservação da araucária nas propriedades rurais em Minas Gerais.

Palavras-chave: Tensão ecológica; Floresta estacional semidecidual; Extração.

\begin{abstract}
The knowledge of the production and marketing chains of pinhão is centered in the Mixed Ombrophilous Forest region, in southern Brazil. This study aimed to evaluate the pinhão production and marketing chains in a region of ecological tension (Seasonal Semideciduous Forest) and verify the pinhão trade effectiveness as a tool for araucaria conservation. This research was based on a statistical survey on pinhão extraction and trade, made available by governmental institutions. To identify establishments operating in the trade of pinhão in Minas Gerais (Brazil), structured interviews and a literature review of the legislation associated with the trade of forest products were conducted, establishing the relationship between the trade and conservation of araucaria. The results showed that Minas Gerais is the third-largest national producer of pinhão, accounting for $13.9 \%$ of production, and receiving the lowest remuneration for the extracted product. There is a predominance of a short marketing chain, in which producers or retailers negotiate with the consumer, resulting in greater profits for those involved in this process, who benefit from the lack of specific regulations and inspections in the extraction and trade of pinhão, leading to a predatory activity, which does not contribute to the preservation of araucaria. However, the use of appropriate instruments may make feasible the conservation of this species, combining its potential for use in forest restoration projects with the income from the commercialization of its seeds, thus developing an effective tool for the conservation of araucaria in rural properties in Minas Gerais.

Keywords: Ecological tension; Seasonal semideciduous forest; Extraction.
\end{abstract}

\section{INTRODUCTION}

Araucaria angustifolia (Bertoloni) Otto Kuntze, popularly known as araucaria, Paraná pine, Brazilian pine, and curi, is a Brazilian forest species, also occurring in small patches in Argentina and Paraguay. It is typical of the Atlantic Forest biome, associated with a Mixed Ombrophilous Forest, called Araucaria Forest, also occurring in areas of ecological tension with the Seasonal Semideciduous Forest and the Dense Ombrophilous Forest. In Brazil, it massively predominates in the southern region and in sparse patches in the south of São Paulo, as well 
as in areas of high altitude in Minas Gerais and Rio de Janeiro (CARVALHO, 2003; FERREIRA et al., 2012; ZECHINE et al., 2012).

Due to rampant exploitation and reduction of native vegetation for the establishment of human activities, araucaria is on the national list of flora species threatened with extinction, classified as a "species in danger of extinction" (Ordinance No. 443/2014 of the Ministry of the Environment). Currently, araucaria produces highvalue wood and is appreciated by sawmills, joinery, carpentry, and furniture industry, but it also stands out for providing non-timber forest products (NTFP), i.e., its seeds (pinhão). Because of their significant energy reserves, araucaria seeds have become an important source of starch in the diet of humans, domestic animals, and wild fauna (CONFORTI; LUPANO, 2011; DANNER et al., 2012; ALBIERO JUNIOR et al., 2015; PALUDO et al., 2016; ZORTÉA-GUIDOLIN et al., 2017).

Roasted or boiled are the most common forms of consumption of pinhão by humans, being an important heritage from traditional populations in the southern region of Brazil (DANNER et al., 2012), creating a very important production chain in the states of Paraná, Rio Grande do Sul, and Santa Catarina. Some studies Santos et al., 2002; Silva and Reis, 2009; Brandt and Nodari, 2011; Figueiredo Filho et al., 2011; Danner et al., 2012; Zechine et al., 2012; Menegathti et al., 2014; Reis et al., 2014; Jacinto et al., 2016; Silva and Miguel, 2017 emphasize the importance of pinhão for the generation of income and maintenance of the regional culture of the populations of these states. However, there is a great gap regarding the knowledge of the production, use, and commercialization of pinhão in the other states where araucaria naturally occurs.

In this context, this study aimed to evaluate the pinhão production and marketing chains in a region of ecological tension (seasonal semideciduous forest) with the occurrence of araucaria, in Minas Gerais, and verify the pinhão trade effectiveness as a tool for araucaria conservation.

\section{MATERIAL AND METHODS}

The information obtained for the analysis of pinhão production in Minas Gerais was based on official data published annually by the Brazilian Institute of Geography and Statistics (IBGE).

The municipality of Barbacena (Minas Gerais) was selected for analyzing the pinhão marketing chains. The selection of the study area was motivated by the predominant forest, the Montana Semideciduous Seasonal Forest (CARVALHO et al., 2008), where araucaria naturally occurs, in Brazil (CARVALHO, 2003), at an average altitude of 1,164 $\mathrm{m}$ and under Cwb climate (wet temperate), according to Köppen classification (BARBACENA, 2004). These conditions favor the development of this species. Moreover, the municipality is located in a region of Minas Gerais that promotes trade with large urban centers.

Information on the volumes sold and prices of pinhão, in Barbacena, was obtained from the Supply Centers of S. A. Minas Gerais (Ceasaminas), through a census conducted from March to June 2017. All points of sale (trade stalls) were identified and mapped based on information obtained from the City Hall of Barbacena (PMB), the State Forestry Institute (IEF), the Technical Assistance and Rural Extension Company of Minas Gerais (Emater), and the Military Environment Police of Minas Gerais (PMMG). The information was collected using a structured questionnaire, addressing the following questions:

a) "What is the volume (kg) of pinhão sold weekly?";

b) "How much $(\mathrm{R} \$ / \mathrm{kg})$ of pinhão is sold weekly?";

c) "Does this establishment have an environmental license to sell pinhão?";

d) "How is the pinhão obtained for commercialization?".

Subsequently, bibliographic and documentary research on the legislation of araucaria conservation and commercialization of its seeds was carried out, in a national and state (Minas Gerais) context. This allowed us to analyze the period in which the pinhão is collected and sold, its regulation, and how this extraction chain influences the conservation of araucaria.

\section{RESULTS}

\section{Production and trade of pinhão in Minas Gerais}

The production of pinhão in Brazil from 2014 to 2017 is shown in Table 1. 
Tabela 1. Produção brasileira de pinhão e valor unitário remunerado aos extratores no período de 2014 a 2017. Table 1. Brazilian production of pinhão and unit value paid to collectors from 2014 to 2017.

\begin{tabular}{lrrrrrrrr}
\hline State & 2014 & \multicolumn{2}{c}{2015} & \multicolumn{2}{c}{2016} & \multicolumn{2}{c}{2017} \\
& Production (t) & $\begin{array}{c}\text { Value } \\
(\mathrm{R} \$ / \mathrm{kg})\end{array}$ & Production (t) & $\begin{array}{c}\text { Value } \\
(\mathrm{R} \$ / \mathrm{kg})\end{array}$ & Production (t) & $\begin{array}{c}\text { Value } \\
(\mathrm{R} \$ / \mathrm{kg})\end{array}$ & Production (t) & $\begin{array}{c}\text { Value } \\
(\mathrm{R} \$ / \mathrm{kg})\end{array}$ \\
\hline Minas Gerais & 1,162 & 1.60 & 1,213 & 1.68 & 1,090 & 1.65 & 1,294 & 1.54 \\
Paraná & 3,582 & 2.07 & 3,220 & 2.49 & 3,183 & 2.60 & 3,596 & 2.77 \\
Rio Grande do Sul & 881 & 2.71 & 762 & 3.13 & 805 & 3.88 & 947 & 2.84 \\
Santa Catarina & 3,157 & 2.43 & 3,192 & 2.74 & 2,663 & 3.45 & 3,456 & 2.13 \\
São Paulo & 6 & 2.83 & 6 & 2.83 & 6 & 3.33 & 6 & 3.33 \\
\hline Brazil & 8,778 & 2.20 & 8,393 & 2.52 & 7,747 & 2.89 & 9,299 & 2.47 \\
\hline
\end{tabular}

Source: Adapted from IBGE (2018).

There was annual seasonality in the production of pinhão in Minas Gerais, with the lowest harvest in 2016 and the highest volume in 2017, accounting for 1,294 tons of seeds, which correspond to 13.9\% of the Brazilian harvest (Table 1). Minas Gerais was the third largest national producer, behind the states of Paraná $(38.7 \%)$ and Santa Catarina $(37.1 \%)$ and followed by Rio Grande do Sul $(10.2 \%)$ and São Paulo $(0.1 \%)$. In 2017, the pinhão collected in Minas Gerais were sold at an average price of $\mathrm{R} \$ 1.54 / \mathrm{kg}$, which was the lowest remuneration among Brazilian states that extract this seed. This value was $37.6 \%$ lower than the national average.

In Minas Gerais, the municipalities that produce pinhão are located in two administrative mesoregions: South/Southwest of Minas and Campo das Vertentes (Figure 1).

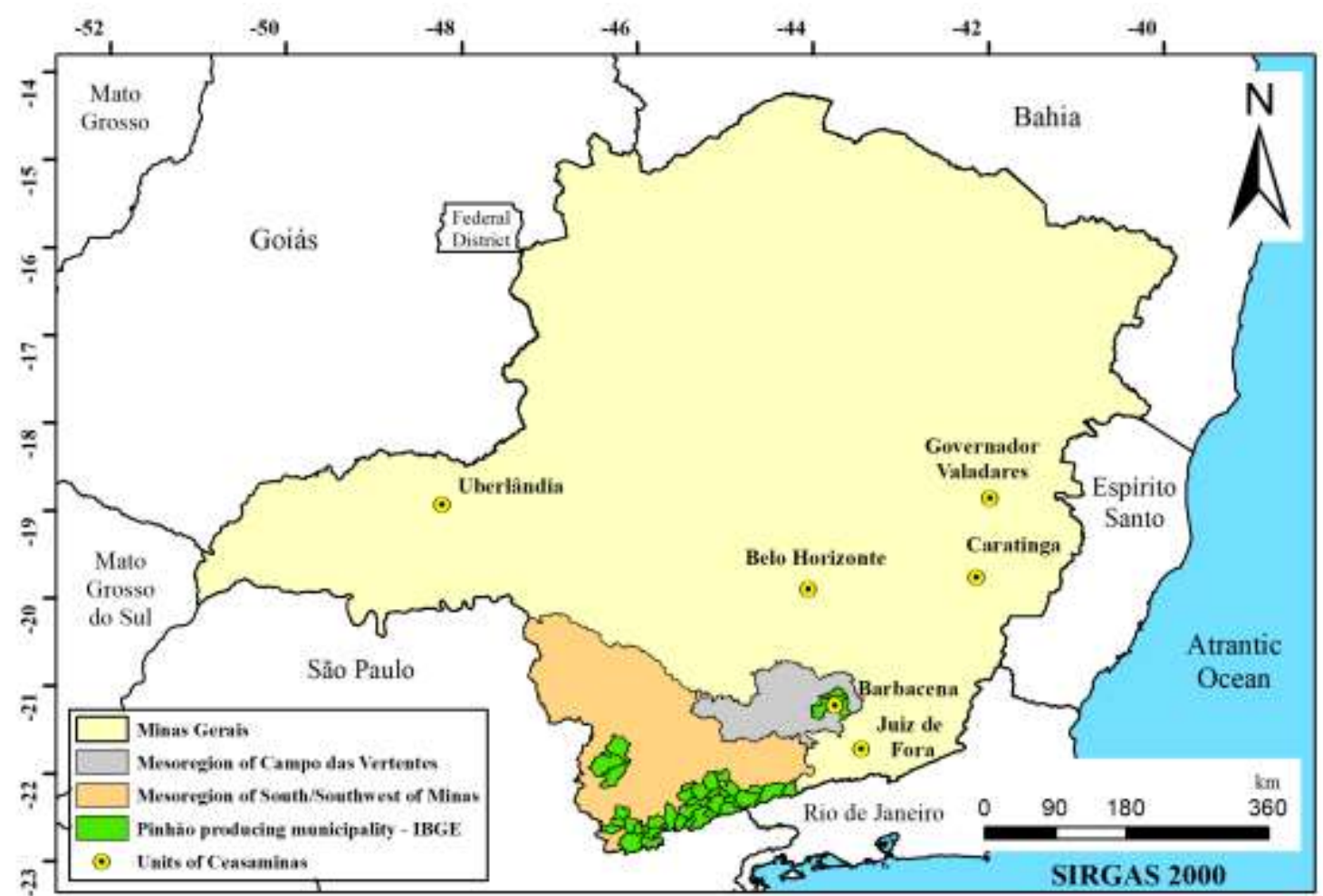

Source: By the authors (2019).

Figura 1. Localização das mesorregiões com os municípios produtores de pinhão e das unidades de comercialização do Ceasaminas no estado de Minas Gerais.

Figure 1. Location of the mesoregions including the pinhão producing municipalities and the Ceasaminas commercial units in the state of Minas Gerais, Brazil.

The pinhão production in Minas Gerais in 2017 comprised 37 municipalities, 34 of which, in the South/Southwest of Minas, were responsible for $99.4 \%$ of the harvest, among them, the municipality of Gonçalves was the largest regional and state producer. The rest of the harvest occurred in 3 municipalities in Campo das Vertentes, in which Barbacena was the largest producer in this mesoregion (Table 2).

FLORESTA, Curitiba, PR, v. 51, n. 2, p. 346-353, abril/jun 2021. 
Tabela 2. Produção de pinhão por mesorregião administrativa do estado de Minas Gerais, valor unitário remunerado aos extratores, número de munícipios produtores e maior produtor no ano de 2017.

Table 2. Pinhão production per administrative mesoregion in the state of Minas Gerais, the unit value paid to collectors, number of producing municipalities, and the largest producer in 2017.

\begin{tabular}{lcccc}
\hline Administrative mesoregion & $\begin{array}{c}\text { Production } \\
(\mathrm{t})\end{array}$ & $\begin{array}{c}\text { Value } \\
(\mathrm{R} \$ / \mathrm{kg})\end{array}$ & $\begin{array}{c}\text { Producing } \\
\text { municipalities } \\
(\text { No.) }\end{array}$ & $\begin{array}{c}\text { Main producer } \\
\text { (\% of production) }\end{array}$ \\
\hline Campo das Vertentes & 8 & 1.75 & 3 & Barbacena (62.5\%) \\
South/Southwest of Minas & 1,286 & 1.54 & 34 & Gonçalves $(30.4 \%)$ \\
\hline Minas Gerais & 1,294 & 1.54 & 37 & Gonçalves (30.2\%) \\
\hline
\end{tabular}

Source: Adapted from IBGE (2018).

In Minas Gerais, six units of the Ceasaminas commercialize agricultural products: Belo Horizonte, Uberlândia, Barbacena, Juiz de Fora, Caratinga, and Governador Valadares (Table 3). Relationships are established between intermediaries, wholesalers, and retailers in these units, in which the pinhão is one of the products sold.

During the study period, it was observed that the pinhão was commercialized in four units Belo Horizonte, Uberlândia, Barbacena, and Juiz de Fora. Belo Horizonte and Uberlândia alternated in the first rank, accounting for $89.7 \%$ of the volume of pinhão sold in the Ceasaminas, in 2017. These units also had the highest values regarding the sale of pinhão due to not being in producing regions, which results in the addition of freight costs and intermediaries for the commercialization of pinhão.

Tabela 3. Comercialização de pinhão e valor do produto praticado nas unidades do Ceasaminas no período de 2014 a 2017.

Table 3. Commercialization of pinhão and its value in the Ceasaminas units, from 2014 to 2017.

\begin{tabular}{|c|c|c|c|c|c|c|c|c|}
\hline \multirow{2}{*}{$\begin{array}{l}\text { Units of the } \\
\text { Ceasaminas }\end{array}$} & \multicolumn{2}{|c|}{2014} & \multicolumn{2}{|c|}{2015} & \multicolumn{2}{|c|}{2016} & \multicolumn{2}{|c|}{2017} \\
\hline & Trade (kg) & $\begin{array}{c}\text { Value } \\
(\mathrm{R} \$ / \mathrm{kg})\end{array}$ & Trade $(\mathrm{kg})$ & $\begin{array}{c}\text { Value } \\
(\mathrm{R} \$ / \mathrm{kg})\end{array}$ & Trade $(\mathrm{kg})$ & $\begin{array}{l}\text { Value } \\
(\mathrm{R} \$ / \mathrm{kg})\end{array}$ & Trade (kg) & $\begin{array}{l}\text { Value } \\
(\mathrm{R} \$ / \mathrm{kg})\end{array}$ \\
\hline Barbacena & 0 & 0.00 & 1,920 & 1.56 & 744 & 1.96 & 120 & 2.18 \\
\hline Caratinga & 0 & 0.00 & 0 & 0.00 & 0 & 0.00 & 0 & 0.00 \\
\hline Governador Valadares & 0 & 0.00 & 0 & 0.00 & 0 & 0,00 & 0 & 0.00 \\
\hline Belo Horizonte & 2,085 & 2.19 & 3,220 & 1.87 & 2,060 & 2.21 & 10,280 & 3.12 \\
\hline Juiz de Fora & 560 & 1.64 & 1,700 & 1.32 & 0 & 0.00 & 120 & 1.75 \\
\hline Uberlândia & 1,464 & 4.52 & 9,870 & 4.05 & 12,056 & 0.00 & 3,880 & 3.81 \\
\hline Minas Gerais & 4,109 & 2.85 & 16,710 & 3.07 & 14,860 & 5.30 & 14,400 & 3.29 \\
\hline
\end{tabular}

\section{Commercialization of pinhão in the municipality of Barbacena}

A total of five tons of pinhão were extracted in Barbacena in 2017, which were sold by extractors for an average value of $\mathrm{R} \$ 1.75 / \mathrm{kg}$ (IBGE, 2018). That same year, the commercialization of pinhão in the local Ceasaminas was only $120 \mathrm{~kg}$, sold at an average price of $\mathrm{R} \$ 2.18 / \mathrm{kg}$ (Table 3). For the research on the local commercialization of pinhão points of trade, establishments involved, volume and price of the product sold were surveyed (Table 4).

Tabela 4. Pontos com comercialização de pinhão no município de Barbacena apresentando o número de bancas existentes, volume comercializado por quinzena e preço praticado no ano de 2017.

Table 4. Commercial points, number of stalls, volume sold per fortnight, and price of the pinhão in the municipality of Barbacena, in 2017.

\begin{tabular}{|c|c|c|c|c|c|c|c|c|c|c|}
\hline \multirow{3}{*}{$\begin{array}{l}\text { Commercial } \\
\text { points }\end{array}$} & \multirow{3}{*}{ No. } & \multicolumn{8}{|c|}{ Volume sold $(\mathrm{kg})$} & \multirow{3}{*}{$\begin{array}{l}\text { Value } \\
\text { (R\$/kg) }\end{array}$} \\
\hline & & \multicolumn{2}{|c|}{ March } & \multicolumn{2}{|c|}{ April } & \multicolumn{2}{|c|}{ May } & \multirow{2}{*}{$\begin{array}{l}\text { June } \\
\text { First }\end{array}$} & \multirow{2}{*}{ Year } & \\
\hline & & First & Second & First & Second & First & Second & & & \\
\hline Downtown & 04 & 20 & 170 & 280 & 160 & 120 & 50 & 20 & 830 & 3.69 \\
\hline Saturday fair & 10 & 40 & 210 & 585 & 335 & 150 & 0 & 0 & 1,320 & 3.37 \\
\hline Sunday fair & 07 & 30 & 165 & 380 & 255 & 180 & 0 & 0 & 1,010 & 3.37 \\
\hline Highway BR-040 & 05 & 20 & 260 & 340 & 210 & 50 & 0 & 0 & 880 & 3.70 \\
\hline Highway BR-265 & 01 & 0 & 65 & 95 & 40 & 30 & 20 & 0 & 250 & 3.50 \\
\hline Total & 27 & 120 & 870 & 1.680 & 1.000 & 530 & 70 & 20 & 4,290 & 3.51 \\
\hline
\end{tabular}

Source: By the authors (2018).

FLORESTA, Curitiba, PR, v. 51, n. 2, p. 346-353, abril/jun 2021.

Marques, R. T. et.al.

ISSN eletrônico 1982-4688

DOI: $10.5380 /$ rf.v51 i2. 68781 
Twenty-seven sale establishments (fruit and vegetable stalls) were surveyed in Barbacena, concentrated in five strategic points for public access, which sold 4,290 kg of pinhão in 2017 , being $73.7 \%$ of this commercialization downtown (open markets and fruit stalls). There was no record of pinhão commercialization in warehouses and supermarkets. The product is sold in natura, packed in nylon bags containing $2 \mathrm{~kg}$ of seeds, at an average price of $\mathrm{R} \$ 3.51 / \mathrm{kg}$. The highest prices were recorded in establishments located on the highway BR-040 (Table 4).

The activity was performed from March to July, with $62.5 \%$ of the total volume sold in April. Regarding the origin of the pinhão that drives the commercial network in Barbacena, 24 traders reported having purchased the seeds from extractors in the municipality, three traders collect the pinhão and only one trader reported purchasing the product from the Ceasaminas in Barbacena.

\section{Legislation on pinhão trade and the conservation of araucaria in Minas Gerais}

The Native Vegetation Protection Law (LPVN) (Federal Law No. 12,651/2012), popularly known as the Forest Code, establishes competence for federal, state, and municipal public authorities to create administrative requirements on registration and other forms of control of individuals and legal entities engaged in the extraction, industry or trade of forest products or by-products. In Minas Gerais, the forest and biodiversity protection law (State Law No. 20,922/2013) determines that it is mandatory, for those who sell products or by-products from native or cultivated flora in the state, to register and annually renew the registration at the competent body.

In Barbacena, none of the 27 establishments that commercialize the pinhão reported having an environmental license or registration to carry out the activity. Twenty-two establishments reported having a municipal license for walking trade in Barbacena and five establishments have authorization from the National Department of Transport Infrastructure (Dnit) for using and occupying federal highway edges.

The federal regulation on pinhão harvest and trade was established by the normative ordinance of the extinct Brazilian Institute for Forest Development (IBDF) in 1976 (Department of Commercialization - DC; 20/1976). This regulation prohibits the felling of adult araucaria trees at their seed fall period (April - June) and the harvesting and felling of immature pine cones before April 15, thus determining this date for the beginning of the harvest, transportation, and commercialization of pinhão. Minas Gerais has a specific regulation on araucaria (State Decree No. 46,602/2014), which declares that the remnants of primary and secondary native vegetation and those in the early and middle stages of Araucaria angustifolia must be protected from cutting and permanently preserved, making the cut, the harvest of planted trees and the use of non-wood products from plantations conditional upon the authorization of the competent environmental body.

In the absence of specific regulations for the harvesting and commercialization of pinhão from native forests in Minas Gerais, those involved in these activities are subject to following the federal decree DC-20/1976. This was not observed in the municipality of Barbacena, where $2,670 \mathrm{~kg}$ of pinhão, corresponding to $62.2 \%$ of this chain, was extracted before April 15 (Table 4), a period in which the activity is prohibited.

\section{DISCUSSION}

Minas Gerais stood out in the production of pinhão, ranking third among the producing states in Brazil. When compared to the South region, which comprises $96 \%$ of the original Araucaria Forest cover, this production is significantly lower; however, there is a strong tradition towards the production in the regional culture, consisting of use as human food, with consequent importance for the source of income of local populations (DANNER et al., 2012; SILVA; MIGUEL, 2017).

Pinhão production in Minas Gerais is concentrated in the Serra da Mantiqueira region, in municipalities with a forest cover of seasonal Semi-deciduous Forest and Montana and Alto Montana Ombrophilous forest, areas of ecological tension with the Mixed Ombrophilous Forest. The producing municipalities in the South/Southwest of Minas Gerais account for almost the total pinhão production because of their forest cover of 247,405 hectares, according to a survey by Carvalho et al. (2008), whereas those in Campo das Vertentes account for 15,575 hectares.

When analyzing the commercialization of pinhão, based on the trade chains (short chain and long chain) described by Silva and Miguel (2017), it was observed that the long chain practically does not exist in the state of Minas Gerais. In this type of chain, the pinhão is obtained by consumers after going through commercial transactions between intermediaries, wholesalers, and retailers carried out in warehouses for the trade of agricultural products. Only $1.1 \%$ of the harvest was sold in the Ceasaminas units in 2017. This is quite different from what occurs in the other producing states, which, according to Danner et al. (2012), sold 2,388 tons of pinhão in Supply Centers (Ceasa) in the states of Paraná, Rio Grande do Sul and Santa Catarina, and 1,010 tons in the Company of Warehouses and General Warehouses in São Paulo (Ceagesp), corresponding to 35.6\% of the total production in these states.

Three possibilities were raised for the low commercialization of pinhão in the long chain. The first one, as previously mentioned, is the lack of a cultural tradition towards the consumption of pinhão outside producing

FLORESTA, Curitiba, PR, v. 51, n. 2, p. 346-353, abril/jun 2021. 
regions. The second is the trade with other states, such as São Paulo for being close to the consumer center and being a large market. Santos et al. (2002) found pinhão from Minas Gerais in the Ceasa of Paraná. Finally, it is because the local short chains provide the establishments with greater profitability, since retailers acquire the pinhão directly from extractors and sell the seeds to consumers, excluding intermediaries and thus absorb the pinhão production (SANTOS et al., 2002; SILVA; MIGUEL, 2017).

Barbacena has peculiarities that favor the establishment of a long chain for the commercialization of pinhão because it has a Ceasaminas unit and is close to those in Juiz de Fora $(85 \mathrm{~km})$ and Belo Horizonte (180 $\mathrm{km})$. However, this trade is not significant, since $85.8 \%$ of pinhão are extracted and commercialized in a short chain. This is justified, from a financial point of view, as the local short chain is extremely more attractive for pinhão traders, since they obtain an average profit margin of $102.9 \%$, only weighing, bagging, and transporting the product to the points of sale, and there are no taxes on the pinhão sold. This profit margin is higher than that of Rio Grande do Sul (86.7\%), reported by Silva and Miguel (2017).

The commercial establishments that make up the pinhão trade short chain in Barbacena benefit from the lack of environmental inspection in their activities and, therefore, none of them has the IEF registration for the commercialization of pinhão. Differently, other licenses such as the trade and authorization municipal permit of the Dnit are regularly required by agents of the PMB and the Federal Highway Police.

Because Minas Gerais has no specific regulations for the extraction and trade of pinhão, such as that in Santa Catarina (Law No. 15,457/2011) and Paraná (ordinance of the Environmental Institute of Paraná - IAP; No. 46/2015), which regulate the pinhão harvest from April 1, it should follow the federal norm, which determines that the extraction activities must start on April 15. Considering that, in Brazil, araucaria seed maturation occurs mainly from April to July (CARVALHO, 2003), the closed season makes possible the maturation of pine cones, causing the natural fall of pinhão and providing food for the native fauna, such as cavies, agoutis, hedgehogs, squirrels, rats, jackdaws, parrots, toucans and parakeets (CARVALHO, 2003), as well as promoting the dispersion and natural regeneration of the species. However, there is a lack of scientific studies on the araucaria phenology in Minas Gerais. These studies could assist in the establishment of specific regulations on the date for harvesting the pinhão in the state. Further studies would reinforce what was pointed out by Quintero et al. (2019), who recorded an early start of pinhão maturation in Serra da Mantiqueira.

The lack of inspection in the pinhão extraction and trade activities in Minas Gerais is once again evidenced. It was recorded a volume of $62.2 \%$ of pinhão sold in the study local chain, during the closed season, when the commercialized seeds did not have the typical brown color indicating their physiological maturation. This lack of inspection encourages extractors to harvest the seeds during the forbidden period, as they can bring their proceeds forward and fully use the seeds produced per pine cones, in addition to optimizing and reducing their physical effort required in harvesting activities (BRITO et al., 2018).

The extraction and trade of pinhão make the araucaria a species that can be used in forest restoration projects in regions where it naturally occurs, in which the income from the commercialization of its seeds would contribute to reducing project costs, without the need to cut down trees. This is allowed by the Forest Code for recovering consolidated Permanent Preservation Areas (PPA) and Legal Reserve (RL), using Agroforest Systems (AFS) as low impact agrosilvopastoral activities (LAUDARES et al., 2017). The implementation of a system formed by coffee and araucaria in the south of Minas Gerais is a successful example of AFS, which demonstrated the feasibility of generating income from the production and trade of pinhão, associated with the improvement of the soil physical attributes and the formation of mycorrhiza in coffee trees (MELONI et al., 2018).

Rural afforestation is another form of planting araucaria tree in Minas Gerais. This practice is quite widespread in regions where this species naturally occurs, making it part of the landscape in these regions in Minas Gerais (CRUZ, 2011). The trees are planted in lines on each side of the roads and/or following fences and ditches on the borders of properties, contributing to the scenic beauty, production of pinhão, and dispersion and conservation of the species.

\section{CONCLUSION}

From this study, it is possible to conclude that:

- Minas Gerais has a prominent position in the national scenario of pinhão extraction but due to the lack of tradition towards its consumption, it provides the lowest remuneration to extractors, leading to the establishment of short marketing chains (extractor - traders or final consumer).

- The legislation that prohibits the cutting of araucaria in Minas Gerais and the use of an old federal regulation for the extraction and trade of its seeds have not been sufficient for the conservation of this species, due to the inefficient inspection in this extraction chain.

- Because araucaria provides a NTFP, which allows an economic return without the need to cut down the trees, it has excellent potential for use in forest restoration and rural landscaping projects.

FLORESTA, Curitiba, PR, v. 51, n. 2, p. 346-353, abril/jun 2021.

Marques, R. T. et.al.

ISSN eletrônico 1982-4688

DOI: $10.5380 /$ rf.v51 i2. 68781 
- The pinhão extraction chain can encourage the conservation of Araucaria angustifolia in Minas Gerais and achieve promising results through the implementation of policies for (1) disseminating the consumption of pinhão, (2) supporting the development of regional scientific studies on the phenology and ecology of this species, (3) encouraging its planting, (4) establishing clear rules based on scientific knowledge for the extraction and commercialization of its seeds, and (5) developing inspection strategies for this extraction chain.

\section{ACKNOWLEDGMENTS}

To the Instituto Federal de Educação Ciência e Tecnologia do Sudeste de Minas Gerais (IF Sudeste $\mathrm{MG})$ for the resources that made it possible to carry out this research.

\section{REFERENCES}

ALBIERO JUNIOR, A.; TEMPONI, L. G.; GALVÃO, F.; BOTOSSO, P. C.; GUIMARÃES, A. T. B. Population structure of Araucaria angustifolia in the Iguaçu National Park. Floresta, Curitiba, v. 45, n. 2, p. 361 - $372,2015$.

BARBACENA. Plano municipal de saneamento básico de Barbacena - MG. Barbacena: Prefeitura Municipal de Barbacena, 2014, 727 p.

BRANDT, M.; NODARI, E. S. Comunidades tradicionais da floresta de araucária de Santa Catarina: territorialidade e memória. História Unisinos, São Leopoldo, v. 15, n. 1, p. 80 - 90, 2011.

BRITO, P. C.; LOPES, E. C.; OLIVEIRA, F. M.; RODRIGUES, C. K.; FERT NETO, J.; SOUZA, M. C. de. Carga de trabalho físico e postura na coleta de pinhão na região serrana de Santa Catarina. Floresta, Curitiba, v. 48, n. 2, p. $203-212,2018$

CARVALHO, L. M. T. de; SCOLFORO, J. R. S.; ACERBI JUNIOR, F. W.; SILVEIRA, E. M. de O.; OLIVEIRA, L. T. de. Análises espaciais e estatísticas da flora nativa em Minas Gerais. In: CARVALHO, L. M. T. DE; SCOLFORO, J. R. S. Inventário Florestal de Minas Gerais: monitoramento da flora nativa 2005-2007. Lavras: Editora UFLA, 2008, 375 p.

CARVALHO, P. E. R. Espécies arbóreas brasileiras. Brasília: Embrapa Informação Tecnológica, 2003,640 p.

CENTRAIS DE ABASTECIMENTO DE MINAS GERAIS S. A. - Ceasaminas. Oferta de produtos. Disponível em: <https://minas1.ceasa.mg.gov.br/detec/ofertas_medio_prd/ofertas_medio_prd.php> Acesso em: $05 / 10 / 2018$

CONFORTI, P. A.; LUPANO, C. E. Selected properties of Araucaria angustifolia and Araucaria araucana seed protein. International Journal of Food Properties, Abingdon, v. 14, n. 1, p. 84 - 91, 2011.

CRUZ, E. C. F. Pomares e jardins das fazendas de café: Serra da Bocaina no Vale do Paraíba e Serra da Mantiqueira no Sul de Minas. Labor \& Engenho, Campinas, v.5, n.4, p. 89 - 105, 2011.

DANNER, M. A.; ZANETTE, F.; RIBEIRO, J. Z. O cultivo da araucária para produção de pinhões como ferramenta para a conservação. Pesquisa Florestal Brasileira, Colombo, v. 32, n. 72, p. 441 - 451, 2012.

FERREIRA, P. I.; PALUDO, G. F.; CHAVES, C. L.; BORTOLUZZI, R. L. da C.; MANTOVANI, A. Florística e fitossociologia arbórea de remanescentes florestais em uma fazenda produtora de Pinus spp. Floresta, Curitiba, v. 42, n. 4, p. 783 - 794, 2012.

FIGUEIREDO FILHO, A.; ORELlANA, E.; NASCIMENTO, F.; DIAS, N. A.; INOUE, M. T. Produção de sementes de Araucaria angustifolia em plantio e em floresta natural no centro-sul do estado do Paraná. Floresta, Curitiba, v. 41, n. 1, p. 155 - 162, 2011.

INSTITUTO BRASILEIRO DE GEOGRAFIA E ESTATÍSTICA - IBGE. Produção da extração vegetal e da silvicultura - PEVS. Disponível em: < https://www.ibge.gov.br/estatisticas-novoportal/economicas/agriculturae-pecuaria/9105-producao-da-extracao-vegetal-e-da-silvicultura.html?=\&t=o-que-e> Acesso em: 05/10/2018.

JACINTO, R. C.; BRAND, M. A.; RIOS, P. D.; CUNHA, A. B. da; ALlEGRETTI, G. Análise da qualidade energética da falha de pinhão para a produção de briquetes. Scientia Forestalis, Piracicaba, v. 4, n. 112, p. 821 829, 2016. 
LAUdARES, S. S. de A.; BORGES, L. A. C.; ÁVIlA, P. A. de; OliVEIRA, A. L. de; SilVA, K. G. da; LAUDARES, D. C. de A. Agroforestry as a sustainable alternative for environmental regularization of rural consolidated occupations. Cerne, Lavras, v. 32, n. 2, p. 162 - 173, 2017.

MELLONI, R.; COSTA, N. R.; MELLONI, E. G. P.; LEMES, M. C. S.; ALVARENGA, M. I. N.; NUNES NETO, J. Sistemas agroflorestais cafeeiro-araucária e seu efeito na microbiota do solo e seus processos. Ciência Florestal, Santa Maria, v. 28, n. 2, p. 784 - 795, 2018.

MENEGATTI, R. D.; HIGUCHI, P.; SILVA, A. C.; FERT NETO, J.; CORREIA, J.; MUNARETTI, A. M.; BERRI, P. V. Relação etnobotânica dos proprietários rurais do município de Urupema, SC, com recursos florestais. Floresta, Curitiba, v. 44, n. 4, p. 725 - 734, 2014.

PALUDO, G. F.: DUARTE, R. I.; BERNARDI, A. P.; MANTOVANI, A.; REIS, M. S. dos. The size of Araucaria angustifolia (Bertol.) Kuntze entering into reproductive stages as a basis for seed management projects. Revista Árvore, Viçosa, v.40, n.4, p. 695 - 705, 2016.

QUiNTEIRO, M. M. da C.; ALEXANDRE, B. da R.; MAGAlHÃES, L. M. S. Brazilian Pine (Araucaria angustifolia (Bertol.) Kuntze) ethnoecology in the Mantiqueira Atlantic Forest. Floresta e Ambiente, Seropédica, v. 26, n. 1, p. 1-7, 2019.

REIS, M, S. dos; LADIO, A.; PERONI, N. Landscapes with Araucaria in South America: evidence for a cultural dimension. Ecology and Society, Wolfville, v. 19, n. 2, p. 1 - 14, 2014.

SANTOS, A. J. dos; CORSO, N. M.; MARTINS, G.; BITTENCOURT, E. Aspectos produtivos e comerciais do pinhão no estado do Paraná. Floresta, Curitiba, v. 32, n. 2, p. 163-169, 2002.

SILVA, C. da V.; MIGUEL, L. de A. Os canais de comercialização do pinhão e seus agentes, em São Francisco de Paula, RS. Floresta, Curitiba, v. 47, n. 4, p. 489 - 500, 2017.

SILVA, C. da V.; REIS, M. S. dos. Produção de pinhão na região de Caçador, SC: aspectos da obtenção e sua importância para comunidades locais. Ciência Florestal, Santa Maria, v. 19, n. 4, p. 363 - 374, 2009.

ZECHINI, A. A.; SCHUSSLER, G.; SILVA, J. Z. da; MATTOS, A. G.; PERONI, N.; MANTOVANI, A.; REIS, M. S. dos. Produção, comercialização e identificação de variedades de pinhão no entorno da floresta nacional de Três Barras - SC. Biodiversidade Brasileira, Brasília, v. 2, n. 2, p. 74 - 82. 2012.

ZORTÉA-GUIDOLIN, M. E. B.; DEMIATE, I. M.; GODOY, R. C. B. de; SCHEER, A. DE P.; GREWELL, D.; JANE, J. Structural and functional characterization of starches from Brazilian pine seeds (Araucaria angustifolia). Food Hydrocolloids, Cardiff, v. 63, p. 19 - 26. 2017. 